\title{
JEKK
}

Jurnal Epidemiologi Kesehatan Komunitas

3 (2), 2018, 101-108

\section{Faktor Risiko Penyakit Ginjal Kronik Diabetes (PGK-DM) pada Diabetes Mellitus Tipe-2 \\ (Studi di RSUD DR Soedarso Kota Pontianak Provinsi Kalimantan Barat)}

\author{
Sulistio Rini ${ }^{*}$, Suharyo Hadisaputro ${ }^{* *}$, Lestariningsih ${ }^{* * *}$, Heri Nugroho HS ${ }^{* * *}$, Selamat Budijitno ${ }^{* * *}$ \\ "Dinas Kesehatan Kabupaten Sanggau, "Politeknik Kesehatan Semarang, \\ ${ }^{* * *}$ Fakultas Kedokteran Undip
}

\begin{abstract}
Background: Prevalence of type- 2 diabetes mellitus have increased significantly. The increasing number of people with diabetes has a major impact on the development of chronic diabetic kidney disease. The research was aimed to clarify several risk factors of chronic diabetic kidney disease on type-2 diabetes mellitus (CDK-DM).

Method: The research was based on case control study design. The number of respondents was 140 respondents consisting 70 cases and 70 controls that met the criteria of inclusion and exclusion. The cases were patients with type- 2 chronic diabetic kidney disease stadium 2-5. The controls were patients with type- 2 chronic diabetic kidney disease with blood sugar levels $\geq 200$ $\mathrm{mg} / \mathrm{dL}$. The data were then analyzed using logistic regression.

Results: The result shows that risk factors of chronic diabetic kidney disease in type-2 diabetes mellitus are diabetes in family $(\mathrm{OR}=6,732 ; 95 \% \mathrm{CI}=2,623-17,276)$, high blood pressure $(\mathrm{OR}=$ $6,760 ; 95 \% \mathrm{CI}=2,190-20,867)$, lack of physical activities $(\mathrm{OR}=4,36795 \% \mathrm{CI}=1,823-10,462)$ and lack of family support $(\mathrm{OR}=4,203 ; 95 \% \mathrm{CI}=1,437-12,295)$. The probability of chronic diabetic kidney disease occurrence in type-2 diabetes mellitus when four risk factors exist are $96,71 \%$.

Conclusion: The host factors have important role of chronic diabetic kidney disease in type 2 diabetes mellitus. The factors proven to be risk factors for occurrence of chronic diabetic kidney disease in type 2 diabetes mellitus were diabetic in the family, Hipertension, poor physical exercise and family Support.
\end{abstract}

Keywords : Riskfactors; chronic kidney disease; type-2 diabetes mellitus

*Penulis korespondensi : sulistiorini345@gmail.com 


\section{Pendahuluan}

Satu juta orang dewasa di wilayah Regional Asia Tenggara pada tahun 2015 meninggal karena penyakit ginjal sebagai akibat dari salah satu penyebab komplikasi diabetes melitus dan menempati urutan pertama sebagai penyebab kematian yang diakibatkan komplikasi. ${ }^{1}$ Pada tahun 2014 penyebab kematian tertinggi ketiga di Indonesia adalah diabetes melitus dengan komplikasi sejumlah $6,7 \%$ salah satu komplikasi yang menyebabkan kematian pada penderita diabetes melitus di Indonesia adalah penyakit ginjal kronik stadium lima. ${ }^{2}$

Di Provinsi Kalimantan Barat, kasus diabetes melitus menempati urutan kedua penemuan kasus setelah hipertensi sebagai penyakit tidak menular tertinggi. dengan angka prevalensi tahun 2014 sejumlah 3,6\% dan tahun 2015 sejumlah $3,8 \%$ per 1000 penduduk. sampai dengan data bulan juni tahun 2016 diketahui bahwa jumlah kasus diabetes melitus di Provinsi Kalimantan Barat mencapai 2.974 kasus dengan prevalensi kasus tertinggi berdasarkan jenis kelamin adalah wanita. $^{3}$

Berdasarkan data RSUD DR Soedarso Kota Pontianak pada tahun 2013 jumlah kasus penyakit ginjal akut dan kronik stadium lima sejumlah 324 orang 171 lakilaki dan 153 adalah wanita dengan angka case fatality rate $25,61 \%$ tahun 2014 sejumlah 428 orang 195 laki-laki dan 233 adalah wanita dengan angka case fatality rate $21,49 \%$ tahun 2015 sejumlah 326 orang 134 laki-laki dan 192 adalah wanita dengan angka case fatality rate $23,31 \%$ tahun 2016 penyakit ginjal akut dan kronik stadium limasejumlah 409 orang 208 laki-laki dan 201 adalah wanita dengan angka case fatality rate $16,87 \%$.

Kejadian penyakit ginjal yang disebabkan diabetes melitus meningkat. Karena tren ini, semakin besar proporsi praktik dokter dalam melakukan perawatan primer. Hanya saja pasien penyakit ginjal kronik yang dirujuk dalam kondisi yang sangat terlambat, hal ini menyebabkan kesempatan untuk melakukan intervensi preventif, dengan tujuan menghindari terapi penggantian ginjal hilang. ${ }^{4}$
Diabetes melitus tipe-2 merupakan etiologi penyakit ginjal kronik setelah hipertensi $i^{5}$ dalam hal ini perlu dilakukan evaluasi yang mendalam apakah diabetes melitus tipe- 2 merupakan etiologi atau penyakit penyerta. Dalam penelitian ini akan dilakukan penelitian terkait faktor risiko yang dimiliki host dengan melihat paparan kebelakang.

Penyakit ginjal kronik diabetes di sebabkan oleh berbagai faktor. Tingginya prevalensi dan kematian penyakit ginjal kronik pada diabetes melitus tipe-2 disebabkan oleh interaksi antara faktorfaktor kerentanan genetis dan paparan terhadap lingkungan. ${ }^{6}$

Faktor kerentanan genetis yang dimiliki host dapat memicu terjadinya penyakit ginjal kronik pada diabetes melitus tipe- 2 seiring dengan perkembangan waktu. yaitu yaitu umur, riwayat diabetes pada keluarga, riwayat hipertensi, indeks masa tubuh berlebih, kebiasaan kurang melakukan latihan jasmani (olahraga), kebiasaan merokok. ${ }^{7}$ Ketidakpatuhan pola waktu makan $^{8}$ lama menderita diabetes melitus tipe-2, tingkat pendapatan, jenis kelamin, konsumsi obat AINS ( anti inflamsi non steroid) sebagai faktor risiko penyakit ginjal kronik sedangkan untuk faktor environtment adalah segala faktor risiko yang dapat menyebabkan perubahan gaya hidup dikaitkan dengan dukungan keluarga sebagai bentuk upaya pencegahan dan pengendalian. ${ }^{9}$

Penelitian terkait faktor risiko penyakit ginjal kronik diabetes pada diabetes melitus tipe-2 perlu dilakukan di Kota Pontianak Provinsi kalimantan Barat. Tujuan dari penelitian ini adalah untuk menganalisis faktor-faktor yang berhubungan dengan penyakit ginjal kronik diabetes ( $\mathrm{PGK}-\mathrm{DM}$ ) pada diabetes melitus tipe-2. Dengan diketahuinya faktor tersebut maka perencanaan program yang tepat dapat dilakukan agar tidak menambah beban biaya, waktu perawatan serta mempercepat kesembuhan pasien. Hasil yang diharapkan adalah untuk mengurangi angka kesakitan dan kematian yang disebabkan oleh penyakit ginjal kronik diabetes pada diabetes melitus tipe-2 di Kota Pontianak Provinsi Kalimantan Barat. 
Sampel yang diperoleh menggunakan teknik multistage random sampling terdiri dari 140 orang, 70 sampel kasus dan 70 sampel kontrol. Penelitian ini dilakukan pada juli sampai agustus 2017. Data dikumpulkan menggunakan kuesioner, wawancara dan observasi data rekam medis rumah sakit. Data di analisis dengan menggunakan uji regresi logistik.

\section{Hasil}

Gambaran karakteristik responden menurut diagnosa disajikan pada Tabel 1 . Diketahui bahwa 70 orang merupakan penderita diabetes melitus tipe-2 sebagai kontrol. 70 orang kasus dengan diagnosa PGK-DM terdiri dari $11,4 \%$ stadium 2, stadium $3-5$ masing-masing sejumlah 12,9\%. Gambaran karakteristik responden berdasarkan pekerjaan, pendidikan, dan umur disajikan pada Tabel 2 .

Berdasarkan data Tabel 2 diketahui bahwa mayoritas responden pada kelompok kasus terbanyak adalah wiraswasta $(75,7 \%)$ hampir sama pada kelompok kontrol yaitu wiraswasta $(61,4 \%)$.

Kemudian terkait dengan distribusi tingkat pendidikan responden pada kelompok kasus sebagian besar adalah tamat SMA (80,0\%),hampir sama pada kelompok kontrol yaitu yang mayoritas berpendidikan tamat $\operatorname{SMA}(78,6 \%)$.

Distribusi umur pada kelompok kasus terbanyak adalah umur $<60$ tahun $(90,0 \%)$, umur termuda adalah 34 tahun hingga tertua adalah 80 tahun dengan ratarata umur 49,83 dan terbayak pada umur 55 tahun. Umur pada kelompok kontrol terbanyak adalah umur $<60$ tahun $(84,3 \%)$, umur termuda adalah 37 tahun hingga tertua adalah 77 tahun dengan rata-rata umur 53,99 dan terbayak pada umur 59 tahun.

Analisis bivariat dilakukan untuk mengetahui gambaran kasar hubungan variabel independen dengan dependen melalui "p" ( $p<0,05)$ yang menunjukan signifikansi variabel. Besarnya nilai odds ratio $(\mathrm{OR}=1)$ untuk mengetahui apakah variabel bebas yang diuji merupakan faktor risiko atau bukan terhadap variabel terikat.
Hasil analisis secara bivariat dapat dilihat pada Tabel 3. Dari Tabel 3, menunjukkan bahwa terdapat tujuh variabel independen yang dapat dimasukkan dalam analisis multivariat yaitu diabetes pada keluarga, hipertensi, kebiasaan kurang latihan jasmani atau olahraga, ketidakpatuhan pola waktu makan, lama menderita diabetes melitus tipe-2, tingkat pendapatan, dan dukungan keluarga variabel independen yang dapat dimasukkan dalam analisis multivariat.

Hasil analisis multivariat menunjukkan bahwa dari tujuh variabel yang dianalisis secara bersama-sama, terdapat empat variabel yang secara statistik berhubungan dengan kejadian PGK-DM pada diabetes melitus tipe-2 di RSUD DR Soedarso Kota Pontianak. empat variabel yang berhubungan secara statistik tersebut adalah diabetes pada keluarga hipertensi, kebiasaan kurang latihan jasmani atau olahraga, dan dukungan keluarga .

Hasil analisis menunjukkan bahwa dari tujuh variabel yang dianalisis secara bersama-sama, terdapat empat variabel yang secara statistik berhubungan dengan kejadian PGK-DM pada diabetes melitus tipe-2 di RSUD DR Soedarso Kota Pontianak, adalah diabetes pada keluarga hipertensi, kebiasaan kurang latihan jasmani atau olahraga, dan dukungan keluarga.

$$
\mathrm{p}=\frac{1}{1+(\mathrm{e}-(\mathrm{a}+\beta 1 \mathrm{x} 1+\beta 2 \times 2+\beta 3 \times 3+\ldots \beta \mathrm{xXx}} \quad \times 100 \%
$$

Berdasarkan hasil perhitungan dari persamaan tersebut dapat disimpulkan bahwa peluang apabila diabetes melitus pada keluarga hipertensi / TD $\geq 140 / 90 \mathrm{mmHg}$, kebiasaan kurang latihan jasmani atau olahraga dan dukungan keluarga yang kurang maka probabilitas untuk menyebabkan kejadian PGK-DM pada penderita sebesar $96,71 \%$. 
Tabel.1 Distribusi karakteristik responden menurut diagnosa di RSUD DR Soedarso

\begin{tabular}{clrr}
\hline No. & \multicolumn{1}{c}{ Diagnosa } & $\mathrm{n}$ & $\%$ \\
\hline 1. & DM Tipe 2 & 70 & 50,0 \\
2. & PGK-DM Stadium 2 & 16 & 11,4 \\
3. & PGK-DM Stadium 3 & 18 & 12,9 \\
4. & PGK-DM Stadium 4 & 18 & 12,9 \\
5. & PGK-DM Stadium 5 & 18 & 12,9 \\
\hline \multicolumn{2}{r}{ Total } & 140 & 100 \\
\hline
\end{tabular}

Tabel 2. Distribusi karakteristik responden menurut pekerjaan, pendidikan dan umur di RSUD DR Soedarso

\begin{tabular}{|c|c|c|c|c|c|}
\hline \multirow[t]{2}{*}{ Variabel } & \multirow{2}{*}{ Kategori } & \multicolumn{2}{|c|}{ Kasus } & \multicolumn{2}{|c|}{ Kontrol } \\
\hline & & $\mathrm{n}$ & $(\%)$ & $\mathrm{n}$ & $(\%)$ \\
\hline \multirow[t]{4}{*}{ Pekerjaan } & IRT & 2 & 8,6 & 16 & 22,9 \\
\hline & Pensiunan & 3 & 4,3 & 7 & 10,0 \\
\hline & PNS & 8 & 11,4 & 4 & 5,7 \\
\hline & Wiraswasta & 53 & 75,7 & 43 & 61,4 \\
\hline \multirow[t]{5}{*}{ Pendidikan } & Perguruan Tinggi & 6 & 8,6 & 4 & 5,7 \\
\hline & SD & 3 & 4,3 & 4 & 5,7 \\
\hline & SMA & 56 & 80,0 & 55 & 78,6 \\
\hline & SMP & 5 & 7,1 & 7 & 10,0 \\
\hline & & 70 & 100 & 70 & 100 \\
\hline \multirow[t]{7}{*}{ Umur } & $>60$ Tahun & 7 & 10,0 & 11 & 15,7 \\
\hline & $<60$ Tahun & 63 & 90,0 & 59 & 84,3 \\
\hline & $<60$ Tahun & 49,83 & & 53,99 & \\
\hline & Median & 49,00 & & 56,00 & \\
\hline & Modus & 55 & & 59 & \\
\hline & Minimum & 34 & & 37 & \\
\hline & Maksimum & 80 & & 77 & \\
\hline
\end{tabular}

Tabel 3. Analisis bivariat

\begin{tabular}{|c|c|c|c|c|c|c|c|c|}
\hline \multirow{2}{*}{ No. } & \multirow{2}{*}{ Variabel } & \multicolumn{2}{|c|}{ Kasus } & \multicolumn{2}{|c|}{ Kontrol } & \multirow{2}{*}{ OR } & \multirow{2}{*}{$95 \% \mathrm{CI}$} & \multirow{2}{*}{$\mathrm{p}$} \\
\hline & & $\mathrm{n}$ & $\%$ & $\mathrm{n}$ & $\%$ & & & \\
\hline
\end{tabular}

1. Umur

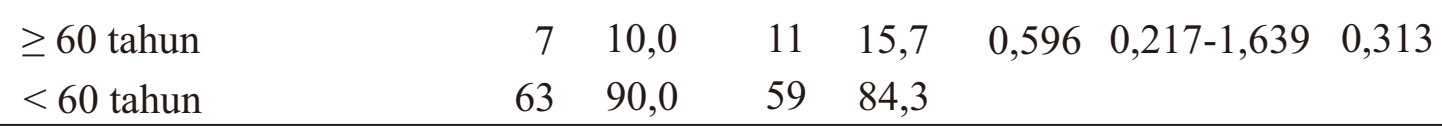

2. Diabetes pada keluarga

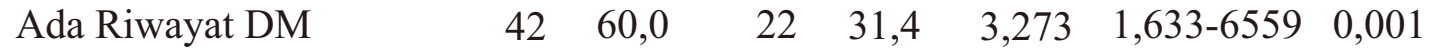

Tidak Ada Riwayat DM $\quad 28 \quad 40,0 \quad 48 \quad 68,6$

3. Hipertensi

Hipertensi TD $\geq 140 / 90 \quad 62 \quad 88,6 \quad 47 \quad 67,1 \quad 3,793 \quad 1,558-9,229 \quad 0,002$

$\begin{array}{lllll}\text { Tidak Hipertensi TD } & 8 & 11,4 & 23 & 32,9\end{array}$

$<140 / 90$ 


\begin{tabular}{|c|c|c|c|c|c|c|c|c|}
\hline \multirow{2}{*}{ No. } & \multirow{2}{*}{ Variabel } & \multicolumn{2}{|c|}{ Kasus } & \multicolumn{2}{|c|}{ Kontrol } & \multirow{2}{*}{ OR } & \multirow{2}{*}{$95 \% \mathrm{CI}$} & \multirow{2}{*}{$\mathrm{p}$} \\
\hline & & $\mathrm{n}$ & $\%$ & $\mathrm{n}$ & $\%$ & & & \\
\hline \multicolumn{9}{|c|}{ 4. IMT } \\
\hline & Overweight $\geq 25 \mathrm{~kg} / \mathrm{m}^{2}$ & 51 & 72,9 & 45 & 64,3 & 1,491 & $0,727-3,060$ & 0,275 \\
\hline & Normal $<25 \mathrm{~kg} / \mathrm{m}^{2}$ & 19 & 27,1 & 25 & 35,7 & & & \\
\hline \multicolumn{9}{|c|}{ 5. $\quad$ Kurang Olahraga } \\
\hline & Tidak olahraga & 42 & 60,0 & 24 & 34,3 & 2,875 & $1,446-5,716$ & 0,002 \\
\hline & Olahraga & 28 & 40,0 & 46 & 65,7 & & & \\
\hline \multicolumn{9}{|c|}{ Kebiasaan merokok } \\
\hline & $\geq 20 \mathrm{btg} / \mathrm{hr}$ & 18 & 25,7 & 24 & 34,3 & 0,663 & $0,320-1,375$ & 0,268 \\
\hline & $\begin{array}{l}\text { MeroKoK } \\
\text { Tidak Merokok }\end{array}$ & 52 & 74,3 & 46 & 65,7 & & & \\
\hline
\end{tabular}

7. Kepatuhan Pola

Waktu Makan

$\begin{array}{llllllll}\text { Tidak Patuh } & 44 & 62,9 & 36 & 51,4 & 1,598 & 0,814-3,137 & 0,268\end{array}$

Patuh

$\begin{array}{llll}26 & 37,1 & 34 & 48,6\end{array}$

8. Lama menderita DM tipe-2

\begin{tabular}{llllllll} 
Lama $\geq 5$ tahun & 58 & 82,9 & 51 & 72,9 & 1,801 & $0,797-4,067$ & 0,154 \\
Tidak Lama $<5$ tahun & 12 & 17,1 & 19 & 27,1 & & & \\
\hline
\end{tabular}

9. Tingkat Pendapatan Kurang

$\begin{array}{llllllll}\text { Rendah dibawah UMR } & 19 & 27,1 & 29 & 41,4 & 0,527 & 0,259-1,071 & 0,075\end{array}$ $\begin{array}{lllll}\text { Tinggi di Atas UMR } & 51 & 72,9 & 41 & 58,6\end{array}$

10. Jenis Kelamin

\begin{tabular}{llllllll} 
Laki-laki & 43 & 61,4 & 44 & 62,9 & 0,941 & $0,475-1,863$ & 0,862 \\
Perempuan & 27 & 38,6 & 26 & 37,1 & & & \\
\hline
\end{tabular}

\begin{tabular}{llllllll}
\hline 11. Mengkonsumsi Obat AINS & & & & & & & \\
$\begin{array}{l}\text { Mengkonsumsi } \\
\text { ibu profen }\end{array}$ & 35 & 50,0 & 40 & 57,1 & 0,750 & $0,385-1,460$ & 0,397 \\
Tidak Mengkonsumsi & 35 & 50,0 & 30 & 42,9 & & & \\
\hline
\end{tabular}

12. Dukungan Keluarga

$\begin{array}{llllllll}\text { Tidak didukung } & 23 & 32,9 & 8 & 11,4 & 3,793 & 1,558-9,229 & 0,002\end{array}$

Didukung

$\begin{array}{llll}47 & 67,1 & 62 & 88,6\end{array}$

Tabel 4. Hasil analisis regresi logistik

\begin{tabular}{clrrrc}
\hline No. & \multicolumn{1}{c}{ Faktor Risiko } & Nilai B & \multicolumn{1}{c}{ OR } & \multicolumn{1}{c}{$95 \% \mathrm{CI}$} & $p$ \\
\hline 1. & Diabetes melitus pada keluarga & 1,907 & 6,732 & $2,623-17,276$ & 0,000 \\
2. & Hipertensi TD $\geq 140 / 90$ mmhg & 1,911 & 6,760 & $2,190-20,867$ & 0,001 \\
3. & Kebiasaan kurang latihan jasmani & 1,474 & 4,367 & $1,823-10,462$ & 0,001 \\
4. & Dukungan keluarga kurang & 1,436 & 4,203 & $1,437-12,295$ & 0.009 \\
& Konstanta & 3,352 & & & \\
\hline
\end{tabular}




\section{Pembahasan}

Berdasarkan analisis statistik regresi logistik dalam Tabel 4, keempat keluarga, kebiasaan kurang latihan jasmani atau olah raga, hipertensi dan dukungan keluraga memiliki pengaruh dengan penyakit ginjal kronik. Hal ini ditunjukkan dengan nilai signifikansi $\mathrm{p}<0,025(\mathrm{p}<0,05)$. Exp (B) Value $=6,732$ yang berarti bahwa penderita dengan diabetes melitus pada keluarga memiliki risiko 6,732 kali untuk mengalami penyakit ginjal kronik diabetes (PGK-DM), $\operatorname{Exp}(\mathrm{B})$ Value $=4,367$ yang berarti bahwa penderita dengan kebiasaan kurang latihan jasmani atau olah raga memiliki risiko 4,367kali untuk mengalami penyakit ginjal kronik diabetes (PGK-DM), Exp (B) Value = 6,760 yang berarti bahwa penderita Hipertensi memiliki risiko 6,760 kali untuk mengalami penyakit ginjal kronik diabetes (PGK-DM), Exp (B) Value $=4,203$ yang berarti bahwa penderita dengan dukungan keluarga yang kurang memiliki risiko 4,203 kali untuk mengalami penyakit ginjal kronik diabetes (PGK-DM).

\section{Diabetes melitus pada keluarga}

Analisis statistik menunjukkan bahwa terdapat pengaruh diabetes pada keluarga dengan kejadian PGK-DM. Keluarga merupakan salah satu faktor risiko utama penyakit ginjal kronik pada diabetes melitus tipe-2. Faktor genetik adalah sesuatu yang diturunkan. Beberapa gen dalam keluarga dianugrahkan dengan kerentanan yang berbeda-beda pada masing-masing populasi. ${ }^{10}$ Penelitian review yang dillakukan oleh Bilious tahun 2008 pada 180 sampel menunjukan hasil bahwa kadar albuminuri meningkat pada pasien homozigot dengan genotip DD. ${ }^{11}$

Berdasarkan hasil wawancara mendalam dengan responden menyatakan bahwa penderita diabetes melitus tipe- 2 umumnya memiliki anggota keluarga yang juga sama menderita diabetes terlepas apakah keluarga dekat atau pun jauh. Berdasarkan data yang diperoleh penderita PGK-DM dengan riwayat keluarga diabetes adalah sejumlah 42 orang, atau $60,0 \%$.

\section{Hipertensi}

Analisis statistik menunjukkan bahwa terdapat pengaruh hipertensi dengan kejadian PGK-DM tipe-2. Penelitian menunjukkan tekanan darah tinggi mungkin merupakan prediktor terpenting bagi penderita diabetes dan dapat berkembang menjadi penyakit ginjal kronis. Dan sangat penting bagi penderita diabetes untuk menjaga tekanan darah mereka lebih rendah dari $130 / 80 .^{12}$ Hasil ini sejalan dengan penelitian Ikawati di Semarang tahun 2016 yang mendapatkan nilai $\mathrm{p}=0,000$. Hasil analisis data tersebut menunjukan bahwa lama menderita hipertensi $\geq 5$ tahun merupakan resiko terjadinya $\mathrm{PGK}$ terminal lebih tinggi dengan $(\mathrm{OR}=10,89,95 \% \mathrm{CI}=$ $3,08-38,59){ }^{13}$

\section{Kebiasaan kurang latihan jasmani atau olahraga}

Analisis statistik menunjukkan bahwa terdapat pengaruh latihan jasmani atau olahraga dengan kejadian PGK-DM hal ini sejalan dengan teori yang mengatakan bahwa latihan jasmani atau olahraga yang dilakukan dengan intensitas sedang atau tinggi serta dilakukan secara teratur menurunkan kadar glukosa darah pada tahap awal latihan produksi glukosa hepatik meningkat dengan penurunan kadar insulin. Kadar glukosa pada orang sehat tetap cukup konstan selama olahraga. ${ }^{14} \mathrm{Hal}$ ini sejalan dengan penelitian Kaufaki tahun 2014 yang mendapatkan hasil bahwa meningkatkan aktivitas fisik dapat, mengurangi kemunduran fungsi fisik dan meningkatkan fisiologis cadangan serta mengurangi kejadian komorbid dan meningkatkan kualitas hidup. ${ }^{15}$

\section{Dukungan Keluarga Kurang}

Analisis statistik menunjukkan bahwa terdapat pengaruh dukungan keluarga dengan kejadian PGK-DM tipe-2. Dukungan keluarga yang kurang berpengaruh pada kejadian penyakit ginjal kronik diabetes (PGK-DM) terutama pada stadium lima. Penelitian yang dilakukan oleh Bestari tahun 2016 di Surabaya menunjukan bahwa pasien 
dengan dukungan keluarga yang kurang akan memiliki 4,2 kali lebih besar untuk mengalami kejadian penyakit ginjal kronik. ${ }^{16}$ Penelitian yang dilakukan oleh Thojampa tahun 2017 menunjukan bahwa dengan mengikuti program dukungan mandiri dan program peningkatan dukungan keluarga hasil kelompok eksperimen penderita DM tipe-2 berubah secara signifikan untuk mengalami kerusakan nefron dengan hasil yang lebih sedikit mengalami kerusakan nefron daripada kelompok kontrol dengan $P$ value $0.000 .^{17}$

\section{Kesimpulan}

Hasil penelitian terhadap penderita diabetes melitus tipe-2 di RSUD DR Soedarso Pontianak

\section{Daftar Pustaka}

1. World Health Organization. 2015. Diabetes Fakta dan Angka.pp.1-2.

2. Kementrian Kesehatan RI. 2014. Data Sampel Registration Survey 2014. Available from: www.depkes.go.id/ article/print/data- sampel-registrationsurvey-2014.

3. Dinas Kesehatan Provinsi Kalbar. 2015. Laporan Surveilans Terpadu Pe nyakit. Pontianak: Penerbit Dinas Kesehatan ProvinsiKalbar.

4. Crawford P, Lerma E. 2008. Treatment Options for End Stage Renal Disease. In: Lerma E, editor. Primary Care Clinics in Office Practice. United State Ameri ca:Elsevier Saunders.pp.407-432.

5. Tjekyan RMS. 2014. Prevalensi dan Faktor Risiko Penyakit Ginjal Kronik di RSUP Dr. Mohammad Hoesin Palembang Tahun 2012. MKS;46(4).pp. 276-281.

6. Ekantari F, Suswardani DL, Yuli Kusumawati. 2012. Hubungan Antara Lama Heamodialisis dan Faktor Komorbitas dengan Kematian Pasien Gagal Ginjal Kronik di RSUD DR. Moewardi. Publikasi.pp.1-5.
7. Carthy MI. 2007. Type 2 Diabetic. In: Wright A, Hastie N, editors. Genes and Common Disease Genetics in Modern Medicine. New Yo r k: Penerbit Cambridge.pp. 344-358.

8. Bo Simona, Musso G, Beccuti G, Fadda M, Fedele D, Gambina R. 2009. Consuming More of Daily Caloric Intake a Dinner Predisposes to Obesity. A 6-Year Population-Based Prospective Cohort Study.PLoS One;2(9).pp.1-9.

9. Wardani AK, Isfandiari MA. 2010. Hubungan Dukungan Keluarga dan Peng endalian Kadar Gula Darah dengan Gejala Komplikasi Mikrovaskuler. J Berk Epidemiol;2(2).pp.1-12.

10. National Institute of Diabetes and Digestive and Kidney Diseases. 2014. At Risk for Kidney Disease.Available from:https://www.niddk.nih.gov/healthinformation

11. Bilous R. 2008. Review Article Microvaskular Disease : What does UKPDS Tell about Diabetic Nephrophaty. Diabetes Med J;2.pp.25-29.

12. National Kidney Foundation. 2016. Diabetes and Chronic Kidney Disease. Available from:https://www. kidney.org/news/newsroom/factsheets/ Diabetes-And-CKD

13. Ikawati K. 2016. Komponen Sindrom Metabolik sebagai Faktor Risiko Penyakit Ginjal Kronik Stadium Terminal Studi di RSUP dr.Kariadi Kota Semarang dan RSUD Kota Semarang. Studi case control. Semarang: Universitas Diponegoro.

14. Schuler G, Linke A. 2008. Diabetes and Exercise. In: Type 2 Diabetes Principles and Practice. 2nd ed. USA: Penerbit Informa Health care;pp. 73-82.

15. Kaufaki P, Greenwood S, Painter P, Mercer T. 2012. The Bases Expert Statement on Exercise Therapy for People with Chronic Kidney Disease.

16. Bestari A. 2016. Pengaruh Dukungan Keluarga dan Status DM terhadap Kualitas Hidup Pasien Hemodialis. J B erk Epidemiol;4(2).pp.200-212. 
17. Thojampa S. 2017. Effects of Self-man gement Support and Family Participation Enhancing Program for Delayed Progression of Diabetic Nephropathy in Thai Adults with Type 2 Diabetes. International Journal Africa Nursing; 7.pp.50-54. 